\title{
ReGIONAL Disparities and Within-COUNTRY INEQUALITY IN THE EUROPEAN UNION
}

\section{LAS DISPARIDADES REGIONALES Y LA DESIGUALDAD INTERNA EN LOS PAÍSES DE LA UNIÓN EUROPEA}

Roberto Ezcurra

Universidad de Navarra roberto.ezcurra@unavarra.es

Recibido: enero de 2019; aceptado: marzo de 2019

\begin{abstract}
This paper examines spatial disparities in terms of development within EU countries, using data for 272 regions in the current 28 member states over the period 1996-2010. The analysis carried out confirms that within-country inequality is an important component of overall inequality across European regions. Indeed, regional inequality increased in most EU countries throughout the study period. The results also underline the relevance of national development for within-country inequality, although the relationship is not linear. The advances in national GDP per capita first increase regional inequality. However, beyond a threshold level, the link turns from positive to negative and richer countries tend to experience lower levels of regional inequality. Moreover, the opening of national borders to international markets is associated with higher regional inequality in the EU countries. At the same time, countries with better quality of government have lower levels of regional inequality. These results do not depend on the specific measure used to quantify the magnitude of regional disparities within the sample countries.
\end{abstract}

Keywords: regional Inequality; Countries; European Union. 
RESUMEN:

Este trabajo examina las disparidades espaciales en términos de desarrollo en el interior de los Estados miembros de la UE. Para ello se utilizan datos correspondientes a 272 regiones pertenecientes a 28 países a lo largo del periodo 1996-2010. El análisis llevado a cabo confirma que la desigualdad en el interior de los diferentes países es un componente importante de la desigualdad espacial observada en el conjunto de la UE. De hecho, la desigualdad regional ha aumentado en la mayoría de los países de la UE durante el período objeto de estudio. Los resultados también ponen de manifiesto la relevancia de los procesos de desarrollo nacional a la hora de explicar la evolución de la desigualdad regional, si bien la relaciōn no es lineal. Los avances del PIB per cápita nacional inicialmente contribuyen a aumentar las disparidades regionales. No obstante, una vez alcanzado un determinado nivel de desarrollo la relaciōn se hace negativa, de forma que los países más desarrollados tienden a experimentar menores niveles de desigualdad regional. Asimismo, la apertura de las fronteras nacionales a los mercados internacionales está asociada con mayores disparidades espaciales. Al mismo tiempo, los países con una mejor calidad institucional se caracterizan por registrar menor desigualdad regional. Estos resultados no dependen de la medida concreta utilizada para capturar la magnitud de las disparidades espaciales en el interior de los diferentes paîses.

Palabras clave: Desigualdad regional, paîses, Uniōn Europea.

JEL classification: R11, R12. 


\section{INTRODUCTION}

The existence of regional differences in terms of development across the European Union (EU) has attracted considerable attention from both scholars and politicians over the last two decades. From an academic perspective, this increasing interest is closely related to the introduction of endogenous growth models and the development of the so-called New Economic Geography (NEG) (Barro and Sala-i-Martin, 1995; Redding, 2013). In contrast with the neoclassical growth model, these contributions tend to underline the self-sustained and spatially selective nature of economic growth, which leads to an uneven distribution of economic activity across space. In any case, regional inequality is not uniquely an European problem, but one common to many countries, both developed and developing (lammarino et al., 2018). Nevertheless, since its creation, the EU has been concerned with the possibility that the advances in the integration process give rise to the emergence of winning and losing regions, which explains the strong emphasis placed on achieving economic and territorial cohesion through the Structural and Cohesion Funds (European Commission, 2017).

The vast majority of studies on spatial disparities in the EU focus their attention on regional differences in terms of development across the EU as a whole, ignoring in many cases the degree of within-country inequality. Nevertheless, the analysis of inequality across regions within each country is relevant for various reasons. First, there is evidence that shows that within-country inequality is an important component of overall inequality across the EU regions (Puga, 2002; Ezcurra and Rodríguez-Pose, 2009). Second, high levels of regional inequality within countries may spark social unrest and grievances and lead to redistributive conflicts between regions, which may contribute to the rise of populism and political instability (Rodríguez-Pose, 2018). Despite its potential importance, however, only a few papers have investigated various potential determinants of regional disparities within EU countries (e.g. Petrakos et al., 2005; Ezcurra and Pascual, 2008; Kyriacou and Roca-Sagalés, 2012). In fact, to the best of our knowledge, none study has examined so far this issue in a sample including the Central and Eastern European countries incorporated into the Union in the last enlargements. In order to fill this gap, the present paper aims to investigate the magnitude and evolution of regional inequality within the current 28 EU member states over the period 1996-2010. Furthermore, the paper explores the role played by different factors in explaining within-country inequality in the EU. 
The analysis carried out confirms that within-country inequality is an important component of overall inequality across European regions. Indeed, regional inequality increased in most EU countries throughout the study period. The results also underline the relevance of national development for within-country inequality, although the relationship is not linear. The advances in national GDP per capita first increase regional inequality. However, beyond a threshold level, the link turns from positive to negative and richer countries tend to experience lower levels of regional inequality. Moreover, the opening of national borders to international markets is associated with higher regional inequality in the EU countries. At the same time, countries with better quality of government have lower levels of regional inequality. These results do not depend on the specific measure used to quantify the magnitude of regional disparities within the sample countries, and they should be taken into account by policy makers in view of the risks that high levels of within-country inequality pose for the European construction project.

The remainder of the paper is organized as follows. After this introduction, section 2 examines the importance of the national component when explaining overall inequality across the EU regions by means of a non-parametric approach. Section 3 quantifies the degree of regional inequality within the EU countries, whereas section 4 explores the relevance of different potential determinants of within-country inequality. The final section offers the main conclusions from the paper.

\section{Regional INEQUALITY IN THE EU: DOES THE NATIONAL COMPONENT MATTER?}

In order to carry out my research, I use GDP per capita in purchasing power standards data drawn from Eurostat for 272 NUTS2 regions belonging to the current 28 EU member states ${ }^{1}$. The study period goes from 1996 to 2010. NUTS2 regions are used in the analysis instead of other possible alternative for two reasons. First, this is the level of territorial disaggregation most commonly employed in the literature on regional disparities in the EU, which facilitates the comparison of our results with those obtained in earlier studies. Second, since the 1989 reform of the Structural Funds, NUTS2 regions are the basic unit for the application of cohesion policies in the EU.

To start with, I examine the external shape of the EU regional distribution of GDP per capita by means of non-parametric techniques. Although these techniques do not require to specify a functional form beforehand, a method to smooth the data must be selected. As is usual in the literature, I use kernel smoothing for the analysis. The estimates are based on an Epanechnikov ker-

\footnotetext{
${ }^{1}$ NUTS is the French acronym for "Nomenclature of Territorial Units for Statistics", a hierarchical classification of subnational territorial units established by Eurostat according to administrative criteria. In this classification, NUTSO corresponds to the country level, while increasing numbers indicate increasing levels of spatial disaggregation.
} 
nel function, while the smoothing parameter is selected following the solve-theequation plug-in method proposed by Sheater and Jones (1991)2. The kernel density estimates are shown in Figure 1. When interpreting the graph it should be noted that, in order to facilitate comparisons and remove from the analysis the influence of absolute changes over time, each region's GDP per capita is normalized according to the EU average. The results show clearly that there are important disparities in terms of GDP per capita across the European regions. The estimated density functions are characterized by the presence of two modes. In addition to the main mode, which is located slightly above the EU average, there is an additional mode below $50 \%$ of the EU average. This second mode is formed by Central and Eastern European regions, which confirms the important increase in the magnitude of regional disparities within the EU derived from the incorporation of the new member states. In fact, as a consequence of the last eastward enlargements of the Union, the traditional North-South divide has been replaced by a new North/West-East divide (Ezcurra and Rapún, 2007; Ezcurra, 2014). In any case, Figure 1 reveals that the initial situation has not remained stable between 1996 and 2010. Namely, the number of regions with a GDP per capita below $50 \%$ of the EU average has decreased over the study period. At the same time, there has been an increase in the density concentrated between 75 and $125 \%$ of the EU average. Although these trends suggest that regional disparities has decreased over the study period, there are still important differences in GDP per capita across the EU regions (European Commission, 2017).

Figure 1: EU-RELATIVE REGIONAL DISTRIBUTION OF GDP PER CAPITA.

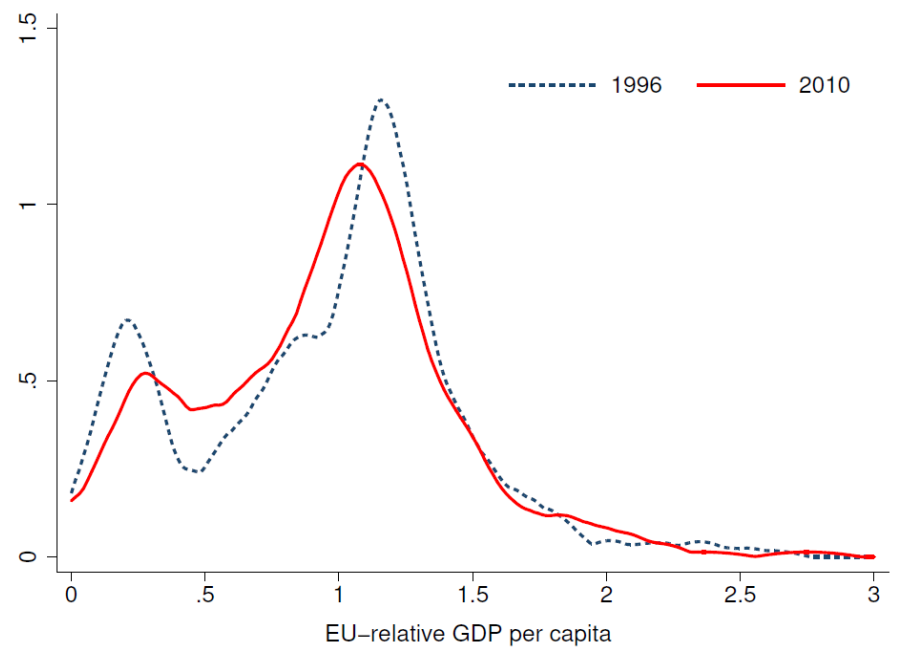

${ }^{2}$ The results are very similar whether a Gaussian kernel function and the smoothing parameter suggested by Silverman (1986) are used alternatively. 
When considering these findings, it is important to recall the importance of country- specific factors in regional growth processes (Ezcurra et al., 2005a,b). In order to examine the relevance of the national component, I follow Quah (1996) and construct a conditioned distribution obtained by normalizing the GDP per capita of each region according to the average GDP per capita of the country to which it belongs. This conditioned distribution can be interpreted as that part of the original distribution that remains unexplained by the socalled country effect. Figure 2 presents the kernel density estimates of the conditioned distribution just defined. If we compare the results with those in Figure 1, we can see that there exists a greater concentration of density around the average, which is a clear indication of the importance of the national component in this context. Nevertheless, Figure 2 also shows that there are still significant differences in terms of GDP per capita between regions within countries (Puga, 2002; Ezcurra and Rodríguez-Pose, 2009). As mentioned in the introduction, this issue is potentially important from a policy perspective. For this reason, the rest of the paper is devoted to examining in detail existing disparities across regions within the different EU member states.

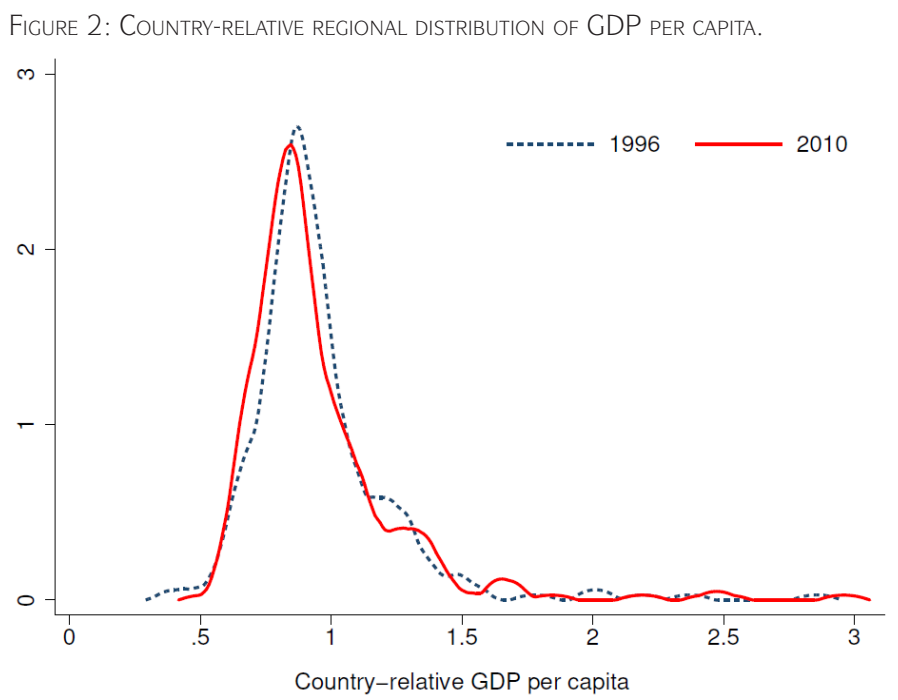

\section{REGIONAL INEQUALiTY WITHIN COUNTRIES}

This section aims to quantify the magnitude of regional inequality within the EU countries. To do this, the most straightforward approach is to calculate some of the numerous measures of inequality existing in the literature. Nevertheless, at this point it is important to take into account that different 
measures of inequality may provide different results, as each index has a different way of aggregating the information contained in the distribution under study (Ezcurra and Rodríguez-Pose, 2009; Lessmann, 2014). For this reason, I use different measures of regional inequality. In particular, I employ the coefficient of variation $(\mathrm{CV})$, the Gini index $(G)$, and two indices proposed by Theil (1967) within the information theory context ( $T(0)$ and $T(1))$. These measures can be expressed as follows:

$$
\begin{gathered}
C V_{i t}=\frac{1}{\mu_{i t}}\left[\sum_{j=1}^{J} p_{j t}\left(y_{j t}-\mu_{i t}\right)^{2}\right]^{0.5} \\
G_{i t}=\frac{1}{2 \mu_{i t}} \sum_{j=1}^{J} \sum_{k=1}^{J} p_{j t} p_{k t}\left|y_{j t}-y_{k t}\right| \\
\boldsymbol{T}(\mathbf{0})_{\boldsymbol{i t}}=\sum_{j=\mathbf{1}}^{j} p_{j t} \log \left(\frac{\boldsymbol{\mu}_{\boldsymbol{i t}}}{\mathbf{y}_{\boldsymbol{j} \boldsymbol{t}}}\right) \\
\boldsymbol{T}(\mathbf{1})_{i t}=\sum_{j=1}^{j} p_{j t}\left(\frac{\mathbf{y}_{\boldsymbol{j} \boldsymbol{t}}}{\boldsymbol{\mu}_{\boldsymbol{i t}}}\right) \log \left(\frac{\mathbf{y}_{\boldsymbol{j} \boldsymbol{t}}}{\boldsymbol{\mu}_{\boldsymbol{i t}}}\right)
\end{gathered}
$$

where $y_{j t}$ and $p_{j t}$ are respectively the GDP per capita and population share of region $j$ in country $i$ during year $t$, and $\mu_{i t}=\sum_{j=1}^{J} p_{j t} y_{j t}$. The advantage of these measures over other potential alternative indices is that they are independent of scale, and they satisfy the population principle and Pigou-Dalton transfer principle (Cowell, 1995; Ezcurra and Rodríguez-Pose, 2013; Kyriacou et al., 2015). Furthermore, these indices take into account the differences in population size across the regions in a country, which is particularly important in the present context. This issue has traditionally been overlooked by the literature on regional convergence, despite the fact that omitting population size significantly affects our perceptions of regional inequality (Petrakos et al., 2005; Lessmann, 2014).

Table 1 summarizes the findings obtained when $C V, G, T(0)$ and $T$ (1) are calculated for the various EU countries ${ }^{3}$. Although there are some minor discrepancies in the rankings generated by the different measures, ${ }^{4}$ the results reveal that the countries with the highest levels of regional inequality over the study period are Slovakia, Hungary, Romania, United Kingdom and the Czech Republic. At the other end of the scale, we find Croatia, the Netherlands, Denmark, Slovenia and Ireland, which are characterized by the lowest levels of dispersion in the regional distribution of GDP per capita between 1996

\footnotetext{
3 The regional population data were drawn from Eurostat.

${ }^{4}$ Table A1 in the Appendix shows the bivariate correlation coefficients between $C V, G, T(0)$ and $T(1)$.
} 
and 2010. The information provided by Table 1 also shows the absence of a clear evolutionary pattern across the EU countries. In 15 out of 22 countries included in the analysis, regional inequality has increased over the study period $^{5}$. At the same time, regional inequality has decreased in Austria, Germany, Portugal, Spain and Sweden. Finally, in the cases of Belgium and Slovenia, the existence of regional convergence or divergence depends on the measure of inequality employed, which highlights the importance of using various alternative indices in this type of analysis (Ezcurra and Rodríguez-Pose, 2009).

\section{EXPLORING THE DETERMINANTS OF WITHIN-COUNTRY INEQUALITY IN THE EU}

\section{1. THE MODEL}

In this section I explore some determinants of regional inequality within the EU coun- tries. To that end, I estimate the following model:

$$
I_{i t}=\alpha+\beta^{\prime} X_{i t}+\lambda_{t}+\varepsilon_{i t}
$$

where $I_{i t}$ is the measure of regional inequality in country $i$ and year $t$, whereas $X_{i t}$ is a set of variables that control for different factors that according to the literature are assumed to have an influence on regional disparities. In turn, $\lambda_{t}$ are year dummies common to all countries, and $\varepsilon_{i t}$ is the corresponding error term.

The regressors included in $X_{i t}$ have been selected on the basis of a careful review of existing studies on the determinants of regional inequality ${ }^{6}$. To start with, it is important to note that the level of regional disparities within each country may be affected by the average size of the territorial units used to compute the measures of regional inequality described in section 3. This is especially relevant in our analysis, as the average size of NUTS2 regions differs considerably among countries. Hence and despite the fact that the values of the dependent variable have already been calculated taking into account the differences in population size across regions, I also control for the average size of regions in each country as a way to minimize any potential bias emerging from the heterogeneity in territorial levels across countries (Ezcurra and Rodríguez-Pose, 2017).

The literature has paid particular attention to the role played by the level of economic development in explaining regional disparities within countries (e.g. Petrakos et al., 2005; Barrios and Strobl, 2009; Lessmann, 2014). This interest goes back to the publication of the seminal study by Williamson (1965), who adopted the Kuznets hypothesis to a spatial framework. According

${ }^{5}$ Cyprus, Estonia, Latvia, Lithuania, Luxembourg and Malta were removed from this analysis because these countries include only one NUTS2 region.

${ }^{6}$ The sources and definitions of all the variables considered in this section are presented in the Appendix. 


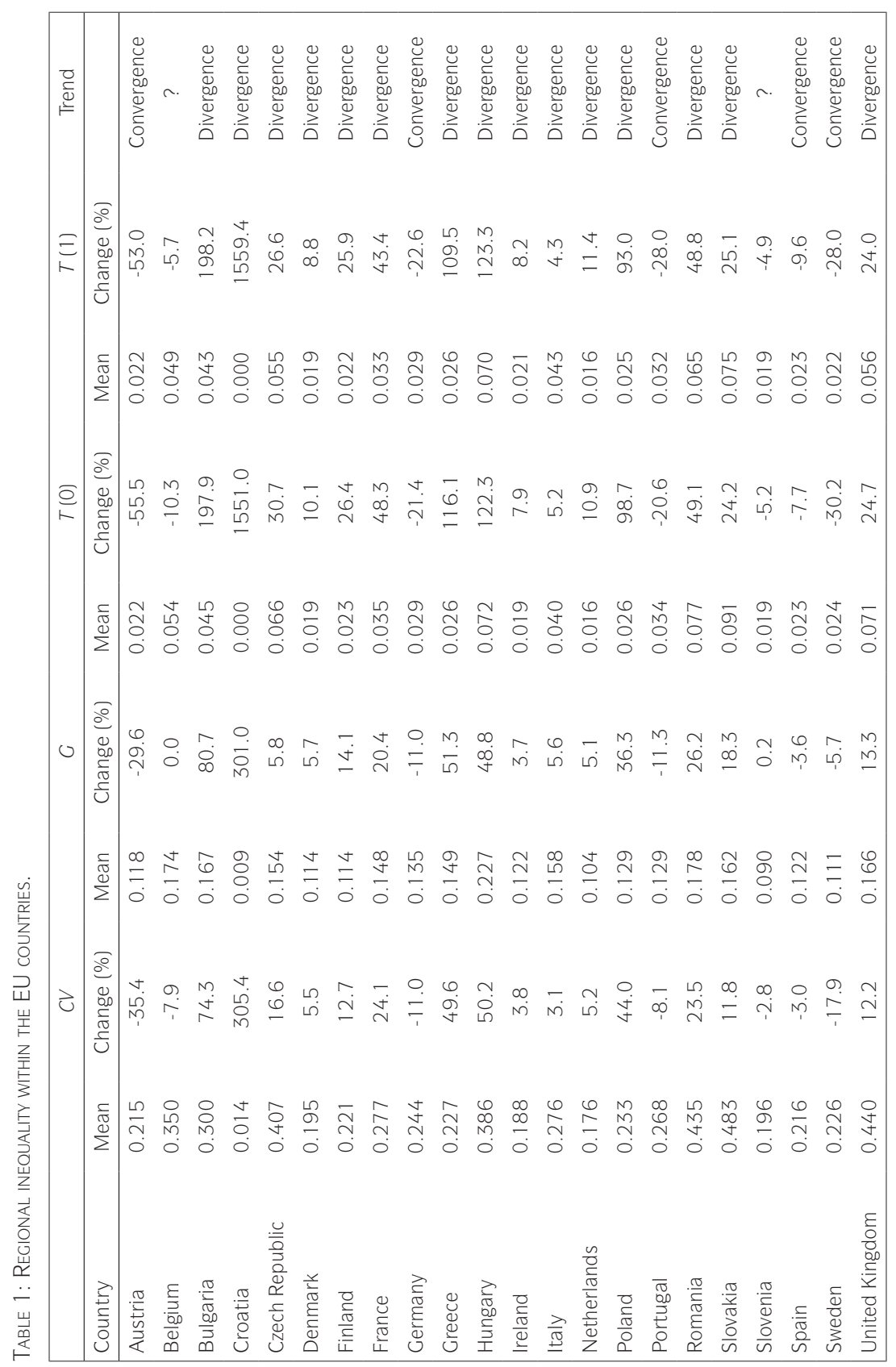


to Williamson (1965), the advances in the process of economic development initially increase regional inequality, before systematically de- creasing it over the ensuing stages of development. This results in an inverted U-shaped relationship between regional inequality and economic development. From a theoretical perspective, in the early stages of economic development, increasing returns and agglomeration economies explain the accumulation of activity and income in the initially more dynamic areas, giving rise to an uneven spatial development. Nevertheless, the existence of diseconomies of agglomeration prevailing after some level of concentration, core-periphery spread effects, technological diffusion processes or transport infrastructure that affect the locational choice of private capital, suggest that, beyond a certain threshold level, economic growth is likely to contribute to the spatial dispersion of economic activity. Taking these arguments into account, and in order to test the possible presence of a non-linear association between regional inequality and economic development, I include in the list of regressors in model (5) the national GDP per capita and its square. Furthermore, I follow Lessmann (2014) and control for share of population living in urban areas as a proxy for potential agglomeration effects, which may affect regional inequality.

Geography may also have an influence on regional inequality. In fact, larger countries are often more heterogeneous than smaller countries (Williamson, 1965). In view of this, I include the area of the various countries in the list of regressors in model (5). Likewise, regional inequality may be sensitive to the existence of physical constraints to mobility, as more topographically-uneven countries tend to experience a greater concentration of economic activity (Ezcurra and Rodríguez-Pose, 2017). Taking this into account, I also control for the standard deviation of elevation and an index of terrain ruggedness.

In the context of the process of globalization currently underway, the possible relationship between trade openness and regional inequality has attracted considerable attention, coinciding with the development of the NEC (e.g. Rodríguez-Pose, 2012; Ezcurra and Rodríguez-Pose, 2013, 2014a). The NEG provides a framework for determining the dynamics of the location of economic activity across regions within a country, which allows one to explore the spatial implications of trade integration. Nevertheless, the NEG models tend to employ different sets of assumptions and functional forms, which often leads to contradictory and ambiguous conclusions regarding the asso- ciation between regional inequality and trade openness (Brülhart, 2011). In fact, some NEG models suggest that trade liberalization increases the internal dispersion of economic activity, thus reducing the level of regional inequality (e.g. Krugman and Livas Elizondo, 1996; Behrens et al., 2007). However, other models underline the existence of a link between trade integration and internal agglomeration, which leads to higher regional disparities (e.g. Monfort and Nicolini, 2000; Paluzie, 2001). Empirical research is therefore key to shedding light on this issue. Accordingly, I control for the degree of trade openness of the the different countries, measured as the ratio between total trade (exports and imports) and GDP. 
The quality of government may also be related to regional inequality (Ezcurra and Rodriguez-Pose, 2014b; Kyriacou et al., 2015). By reducing the degree of uncertainty and transaction costs, government can contribute to facilitating the process of technology diffusion and knowledge transfer across regions, improving the conditions for the development of economic activity in lagging regions (Acemoglu and Robinson, 2012). As Putnam (2000, p. 325) points out, "institutional factors are the key enablers of innovation, mutual learning and productivity growth". At the same time, the quality of government is related to the effectiveness of regional development strategies. Indeed, Rodriguez-Pose and Garcilazo (2015) find that governance influences on the efficiency of Structural and Cohesion Funds expenditure, while Crescenzi et al. (2016) document that the quality of government affects the economic returns of transport infrastructure investment in the EU. Accordingly, I control for the quality of government of the sample countries. To do this, I resort to the the Worldwide Governance Indicators constructed by Kaufmann et al. (1999), which capture six key dimensions of institutional quality: Voice and accountability, Political stability and absence of violence, Government effectiveness, Regulatory quality, Rule of law, and Control of corruption. These six indicators are characterized by very high bivariate correlations (see Table A2 in the Appendix), which suggests that they appear to measure the same broad concept rather than successfully distinguishing between different dimensions of governance (Langbein and Knack, 2010). In order to avoid potential multicollinearity problems, I follow the strategy adopted by various researchers (e.g. Easterly and Levine, 2003; Ezcurra and Rodríguez-Pose, 2014b, 2017) and calculate an aggregate index of government quality equal to the average of the six indicators. In addition to the institutions by which authority is exercised in a country, regional inequality may also be linked to the existence of more or less redistributive policies. I therefore control for the level of public investment as a proxy for the redistributive capacity of the government (Ezcurra and Rodríguez-Pose, 2017).

Decentralization is another factor that may affect regional inequality. According to the prevailing view in the literature, the transfer of authority and resources to subnational governments tends to benefits the most prosperous regions, which generally enjoy better socio-economic endowments and higher quality institutions (Rodríguez-Pose and Ezcurra, 2010). Moreover, decentralization processes may weaken the capacity of central government to play an equalizing role, thus increasing regional inequality (Prud'homme, 1995). On the contrary, other scholars underline that the transfer of power and resources to subnational governments may lead to a reduction in regional inequality, as it may give rise to a more balanced distribution of resources across space. Indeed, Weingast (1995) and Oian and Weingast (1997) show that fiscal decentralization boosts the competition between regions. In order to stay in power, regional governments should attain an economic performance similar to that of the rest of the country. In such a setting, fiscal decentralization allows policy makers in poorer regions to reduce the development gap by offering more flexible labour markets and/or less generous welfare provisions than richer regions. At 
the same time, decentralized countries may have greater incentives to reduce regional inequality because of the risks that regional disparities pose for such countries (Ezcurra and Rodríguez-Pose, 2017). According to these arguments, one should control for the degree of decentralization in the sample countries. To this end, I use an indicator of regional economic self-rule, which captures the degree of authority exercised by subnational governments over those who live in its territory. This indicator is one of the components of the Regional Authority Index developed by Hooghe et al. (2016) and combines information on the level of fiscal and political decentralization in the various countries.

Transition from communism to capitalism is likely to have affected the spatial distribution of economic activity and thus regional inequality. Throughout the 1990s, countries in Central and Eastern Europe underwent profound changes of a political and economic nature as a consequence of the processes of restructuring, privatization, and liberalization that ensued the fall of the Soviet Union. As a result of these changes, regional disparities increased during the transition period in most of these countries (Ezcurra and Pascual, 2007). Consequently, a dummy variable for transition countries is included in model (5).

Finally, ethnic cleavages may also be associated with regional inequality. In fact, Ezcurra and Rodríguez-Pose (2013, 2014b) and Lessmann (2014) find a positive link between ethnic fractionalization and regional inequality. In view of this, I include as an additional control a traditional index of ethnic fractionalization, which measures the probability that two randomly selected individuals in a given country belong to different ethnic groups. This type of index, however, does not take into account the extent to which the members of each group are spatially clustered, ignoring the level of segregation within countries. Nevertheless, ethnic segregation is an important aspect of regional diversity, as ethnic groups often differ in economic terms (Alesina et al., 2016). In fact, the degree of ethnic segregation is likely to be more relevant in this context than the level of ethnic fractionalization (Ezcurra and Rodríguez-Pose, 2017). Accordingly, I also add to the list of covariates a measure of ethnic segregation calculated by Alesina and Zhuravskaya (2011).

Table 2 shows some descriptive statistics for the variables just described, while the corresponding correlation matrix is presented in Table 3. In view of the specification of model (5), one may consider the possibility of including country fixed effects. However, controlling for country fixed effects is not advisable in our case, as this type of models rely exclusively on the time variation within each cross-sectional unit, something which is limited in our dependent variable and in some of the covariates described above. As pointed out by Ezcurra and Rodriguez-Pose (2013, p. 95), in this case fixed effects models leave what is most important in the data unexplained and may consequently produce inaccurate results (Kyriacou et al., 2015). Another possible alternative would be to employ a random effects model. Nevertheless, a random effects model assumes that the individual unobserved effects and the regressors are uncorrelated (Baltagi, 2001), which is unlikely to be satisfied in our case. Therefore, given the characteristics of the dataset, I use pooled 
ordinary least squares (OLS) to investigate the effect of the different variables mentioned above on regional inequality.

TABLE 2: EXPLANATORY FACTORS OF REGIONAL INEQUALITY: DESCRIPTIVE STATISTICS.

\begin{tabular}{|l|c|c|c|c|}
\hline Variable & Mean & Std. Dev. & Min & Max \\
\hline Average size of regions (log) & 9.566 & 0.789 & 7.929 & 11.123 \\
\hline GDP per capita (log) & 10.280 & 0.389 & 9.063 & 10.798 \\
\hline Urban population & 0.709 & 0.122 & 0.500 & 0.976 \\
\hline Area (log) & 11.697 & 0.966 & 9.917 & 13.217 \\
\hline Variation in elevation & 0.236 & 0.146 & 0.019 & 0.579 \\
\hline Ruggedness & 0.173 & 0.125 & 0.021 & 0.447 \\
\hline Trade openness & 0.897 & 0.348 & 0.375 & 1.896 \\
\hline Quality of government & 1.117 & 0.546 & -0.247 & 1.970 \\
\hline Government investment & 0.038 & 0.010 & 0.003 & 0.067 \\
\hline Decentralization & 11.231 & 7.146 & 0.000 & 25.000 \\
\hline Transition & 0.333 & 0.472 & 0.000 & 1.000 \\
\hline Ethnic fractionalization & 0.206 & 0.136 & 0.047 & 0.555 \\
\hline Ethnic segregation & 0.036 & 0.065 & 0.001 & 0.244 \\
\hline
\end{tabular}

\subsection{RESULTS}

Table 4 presents the results obtained when model (5) is estimated with robust standard errors clustered at the country level, using as dependent variables the different measures of regional inequality described in section 3. As can be observed, the model seems to work reasonably well in explaining the cross-country variation in the level of regional inequality within the EU countries, with relatively high values in terms of goodness-of-fit. The results are in general consistent with the findings obtained in other geographical settings. Thus, there is a negative association between the average size of regions and the degree of spatial inequality in a country. The estimates also reveal the existence of an inverted U-shaped relationship between national development and regional inequality, confirming the hypothesis put forward by Williamson and the evidence for Europe provided by Barrios and Strobl (2009). This implies that when the level of GDP per capita is relatively low, the advances in the process of economic development are associated with increasing regional disparities. However, beyond a certain threshold level, the relationship turns from positive to negative and richer countries are likely to experience lower regional inequality ${ }^{7}$. Regional disparities are also greater in larger countries.

\footnotetext{
7 I also examined the possibility that this process of regional convergence does not continue indefinitely and regional inequality may increase again at very high levels of economic development (Lessmann, 2014; Lessmann and Seidel, 2017). To that end, I considered an alternative specification of model (5) with a cubic functional relationship between regional inequality and GDP per capita. The results, however, did not support this hypothesis.
} 


\begin{tabular}{|c|c|c|c|c|c|c|c|c|c|c|c|c|c|c|}
\hline 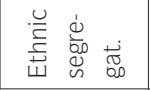 & & & & & & & & & & & & & & 8 \\
\hline 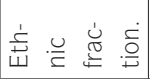 & & & & & & & & & & & & & 8 & $\begin{array}{l}8 \\
8 \\
0 \\
0\end{array}$ \\
\hline 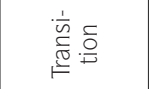 & & & & & & & & & & & & ○ & \begin{tabular}{l}
$\stackrel{9}{1}$ \\
\multirow{1}{+}{} \\
0
\end{tabular} & $\begin{array}{l}\frac{\omega}{\infty} \\
\stackrel{0}{0} \\
1\end{array}$ \\
\hline 岀它这 & & & & & & & & & & & $\begin{array}{l}8 \\
8 \\
-\end{array}$ & $\begin{array}{l}\text { M } \\
\infty \\
+ \\
0 \\
0 \\
1\end{array}$ & $\frac{\bar{N}}{0}$ & $\begin{array}{l}0 \\
\stackrel{N}{N} \\
M \\
0\end{array}$ \\
\hline 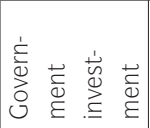 & & & & & & & & & & $\stackrel{8}{8}$ & $\begin{array}{l}\stackrel{+}{\stackrel{N}{N}} \\
\stackrel{0}{1}\end{array}$ & $\begin{array}{l}\text { M } \\
\vdots \\
0 \\
0\end{array}$ & 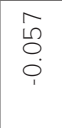 & $\begin{array}{l}\hat{\theta} \\
0 \\
0 \\
0\end{array}$ \\
\hline 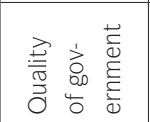 & & & & & & & & & $\begin{array}{l}8 \\
8 \\
\circ \\
-\end{array}$ & $\begin{array}{l}0 \\
6 \\
0 \\
1\end{array}$ & $\frac{\bar{T}}{5}$ & $\begin{array}{l}\frac{\omega}{7} \\
\frac{1}{0} \\
\end{array}$ & $\begin{array}{l}\frac{m}{2} \\
\text { ए? } \\
0 \\
\end{array}$ & $\begin{array}{l}+ \\
0 \\
0 \\
0 \\
0\end{array}$ \\
\hline 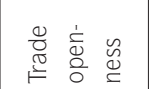 & & & & & & & & 옴 & $\begin{array}{l}\infty \\
\infty \\
0 \\
0 \\
0\end{array}$ & $\frac{\stackrel{0}{v}}{\stackrel{0}{0}}$ & $\begin{array}{l}\frac{\infty}{N} \\
\cdots \\
0\end{array}$ & $\begin{array}{l}\stackrel{\sim}{N} \\
\stackrel{N}{0} \\
0\end{array}$ & $\frac{ \pm}{\pi}$ & 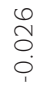 \\
\hline 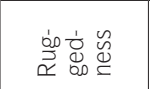 & & & & & & & $\begin{array}{l}8 \\
8 \\
\circ \\
-\end{array}$ & 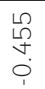 & \begin{tabular}{l} 
v \\
o \\
\multirow{1}{*}{} \\
0
\end{tabular} & $\begin{array}{l}\text { Na } \\
\text { N } \\
0\end{array}$ & $\begin{array}{l}\text { ते } \\
\text { Oे } \\
\text { i }\end{array}$ & $\begin{array}{l}\text { in } \\
0 \\
0 \\
0\end{array}$ & 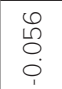 & $\begin{array}{l}\infty \\
0 \\
0 \\
0 \\
0\end{array}$ \\
\hline 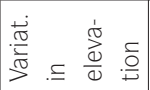 & & & & & & $\begin{array}{l} \\
\circ \\
\circ \\
-\end{array}$ & $\begin{array}{l}0 \\
0 \\
0 \\
0\end{array}$ & 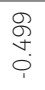 & 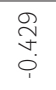 & $\begin{array}{l}\begin{array}{l}0 \\
N \\
0 \\
0\end{array} \\
0\end{array}$ & $\begin{array}{l}N \\
N \\
N \\
0\end{array}$ & $\begin{array}{l}\text { O } \\
\text { Oे } \\
0 \\
\end{array}$ & $\begin{array}{l}\stackrel{O}{O} \\
\text { O } \\
0\end{array}$ & $\begin{array}{l}\stackrel{\llcorner}{N} \\
\stackrel{0}{0} \\
0\end{array}$ \\
\hline 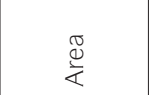 & & & & & ঃ & $\begin{array}{l}\bar{\infty} \\
N \\
\cdots \\
0\end{array}$ & $\frac{N}{0}$ & $\begin{array}{l}\infty \\
0 \\
\emptyset \\
0 \\
0\end{array}$ & $\begin{array}{l}N \\
\stackrel{N}{N} \\
0 \\
0\end{array}$ & $\begin{array}{l}\circ \\
\text { M } \\
O \\
0\end{array}$ & $\begin{array}{l}\stackrel{\llcorner}{\llcorner} \\
\stackrel{\sim}{N} \\
0\end{array}$ & $\begin{array}{l}\hat{0} \\
\cdots \\
0 \\
0\end{array}$ & \begin{tabular}{l}
\multirow{N}{N}{} \\
$\stackrel{0}{1}$
\end{tabular} & $\begin{array}{l}\frac{N}{ \pm} \\
\vdots\end{array}$ \\
\hline 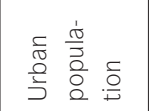 & & & & $\begin{array}{l}8 \\
8 \\
\circ \\
-\end{array}$ & $\frac{\sim}{\sim}$ & $\begin{array}{l}M \\
\infty \\
\infty \\
N \\
0 \\
1\end{array}$ & \begin{tabular}{l} 
o \\
$N$ \\
\multirow{2}{0}{} \\
0 \\
1
\end{tabular} & $\begin{array}{l}\hat{N} \\
\text { Oे } \\
\dot{0}\end{array}$ & $\begin{array}{l}0 \\
\stackrel{\sim}{\sim} \\
\stackrel{1}{0} \\
0\end{array}$ & $\begin{array}{l}\text { En } \\
\stackrel{2}{0} \\
\stackrel{1}{1}\end{array}$ & \begin{tabular}{l}
0 \\
\multirow{v}{*}{} \\
$\dot{0}$
\end{tabular} & $\begin{array}{l}\qquad 0 \\
\infty \\
\llcorner \\
0 \\
0\end{array}$ & $\begin{array}{l}\stackrel{0}{0} \\
0 \\
0\end{array}$ & \begin{tabular}{l} 
o \\
\multirow{1}{+}{} \\
\multirow{0}{0}{} \\
0
\end{tabular} \\
\hline 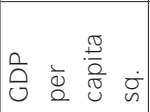 & & & $\stackrel{8}{\circ}$ & $\begin{array}{l}0 \\
\llcorner \\
\llcorner \\
0 \\
0\end{array}$ & \begin{tabular}{l}
\multirow{E}{E}{} \\
$\overline{0}$
\end{tabular} & $\begin{array}{l}\frac{\omega}{2} \\
\frac{1}{1}\end{array}$ & $\begin{array}{l}\text { M } \\
\text { N } \\
\text { Na } \\
\text { i }\end{array}$ & $\begin{array}{l}\circ \\
\stackrel{N}{N} \\
0 \\
0\end{array}$ & $\begin{array}{l}0 \\
N \\
\infty \\
0 \\
0\end{array}$ & 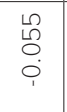 & \begin{tabular}{l}
0 \\
N \\
\multirow{2}{0}{} \\
0
\end{tabular} & $\begin{array}{l} \pm \\
\pm \\
\infty \\
0 \\
1\end{array}$ & 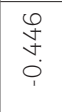 & 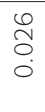 \\
\hline 吕高 & & $\begin{array}{l}8 \\
8 \\
\circ \\
-\end{array}$ & 品 & $\begin{array}{l}\bar{\Gamma} \\
\stackrel{\Gamma}{\llcorner} \\
0\end{array}$ & $\begin{array}{l}E \\
E\end{array}$ & $\begin{array}{l}\frac{1}{5} \\
\dot{0} \\
\end{array}$ & $\begin{array}{l}\stackrel{\llcorner}{\circ} \\
\stackrel{6}{\circ}\end{array}$ & $\begin{array}{l}\stackrel{\infty}{N} \\
\text { Oे } \\
0\end{array}$ & $\begin{array}{l}\hat{M} \\
\infty \\
0\end{array}$ & $\begin{array}{l}\circ \\
\stackrel{1}{0} \\
0 \\
0\end{array}$ & \begin{tabular}{l}
0 \\
$\stackrel{0}{+}$ \\
\multirow{2}{*}{} \\
0
\end{tabular} & $\begin{array}{l}\bar{\sigma} \\
\bar{\infty} \\
0 \\
1\end{array}$ & 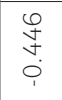 & $\begin{array}{l}\stackrel{\llcorner}{N} \\
\stackrel{0}{0} \\
0\end{array}$ \\
\hline 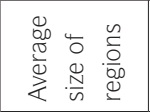 & $\stackrel{8}{8}$ & $\begin{array}{l}\bar{\sigma} \\
\overline{0}\end{array}$ & $\begin{array}{l}\frac{8}{\circ} \\
\frac{0}{1}\end{array}$ & \begin{tabular}{l}
8 \\
$\stackrel{0}{0}$ \\
\multirow{1}{0}{} \\
$i$
\end{tabular} & \begin{tabular}{l}
\multirow{7}{*}{} \\
Lึ \\
0
\end{tabular} & 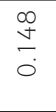 & $\begin{array}{l}0 \\
0 \\
0 \\
0\end{array}$ & $\begin{array}{l}\stackrel{+}{N} \\
\stackrel{\sim}{0}\end{array}$ & 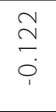 & $\begin{array}{l}\stackrel{\infty}{\sim} \\
\stackrel{+}{+} \\
0\end{array}$ & $\begin{array}{l}\text { No } \\
\text { ָे } \\
0\end{array}$ & $\begin{array}{l}0 \\
0 \\
0 \\
0\end{array}$ & 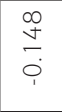 & $\begin{array}{l}\qquad \\
0 \\
0 \\
0\end{array}$ \\
\hline 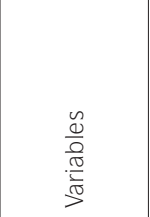 & 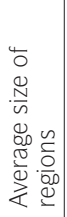 & 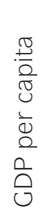 & 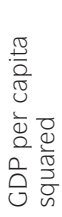 & 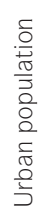 & $\frac{\sqrt[0]{2}}{\frac{1}{\alpha}}$ & 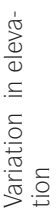 & 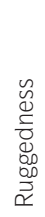 & 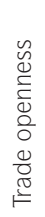 & 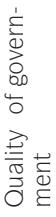 & 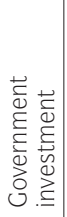 & 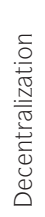 & 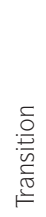 & 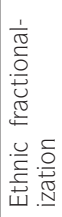 & 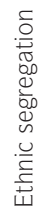 \\
\hline
\end{tabular}


Furthermore, Table 4 indicates that there is a positive association between trade openness and regional inequality (Ezcurra and Rodríguez-Pose, 2014a,b, 2017). This suggests that globalization and the process of economic integration currently underway in Europe lead to the emergence of winning and losing regions within countries, and that the group winning (losing) regions tends to be made up of high-(low-)income regions.

TABle 4: Determinants of REGIONAL InEQUality: RegresSion AnAlysis.

\begin{tabular}{|c|c|c|c|c|}
\hline & $(1)$ & (2) & (3) & (4) \\
\hline Dependent variable & $C V$ & $G$ & $T(0)$ & $T(1)$ \\
\hline Average size of regions & $\begin{array}{c}-0.119 * * \\
(0.046)\end{array}$ & $\begin{array}{c}-0.037^{* *} \\
(0.017)\end{array}$ & $\begin{array}{c}-0.017^{* *} \\
(0.007)\end{array}$ & $\begin{array}{c}-0.022^{* *} \\
(0.009)\end{array}$ \\
\hline GDP per capita & $\begin{array}{c}6.913^{* * *} \\
(1.646)\end{array}$ & $\begin{array}{c}2.187^{* * *} \\
(0.609)\end{array}$ & $\begin{array}{c}1.446 * * * \\
(0.269)\end{array}$ & $\begin{array}{c}1.754 * * * \\
(0.359)\end{array}$ \\
\hline GDP per capita squared & $\begin{array}{c}-0.348^{* * *} \\
(0.084)\end{array}$ & $\begin{array}{c}-0.111^{* * *} \\
(0.031)\end{array}$ & $\begin{array}{c}-0.073^{* * *} \\
(0.014)\end{array}$ & $\begin{array}{c}-0.088^{* * *} \\
(0.018)\end{array}$ \\
\hline Urban population & $\begin{array}{l}-0.034 \\
(0.194)\end{array}$ & $\begin{array}{c}0.118 \\
(0.079)\end{array}$ & $\begin{array}{l}0.002 \\
(0.029)\end{array}$ & $\begin{array}{l}-0.013 \\
(0.038)\end{array}$ \\
\hline Area & $\begin{array}{c}0.109 * * \\
(0.042)\end{array}$ & $\begin{array}{c}0.036 * * \\
(0.014)\end{array}$ & $\begin{array}{c}0.015^{* *} \\
(0.006)\end{array}$ & $\begin{array}{c}0.019 * * \\
(0.008)\end{array}$ \\
\hline Variation in elevation & $\begin{array}{l}0.332^{*} \\
(0.167)\end{array}$ & $\begin{array}{c}0.097 \\
(0.058)\end{array}$ & $\begin{array}{c}0.055^{* *} \\
(0.024)\end{array}$ & $\begin{array}{l}0.068^{*} \\
(0.034)\end{array}$ \\
\hline Ruggedness & $\begin{array}{c}-0.701 * * \\
(0.311)\end{array}$ & $\begin{array}{l}-0.153 \\
(0.117)\end{array}$ & $\begin{array}{c}-0.132 * * \\
(0.047)\end{array}$ & $\begin{array}{c}-0.174^{* * *} \\
(0.060)\end{array}$ \\
\hline Trade openness & $\begin{array}{c}0.162^{* *} \\
(0.073)\end{array}$ & $\begin{array}{c}0.107^{* * *} \\
(0.028)\end{array}$ & $\begin{array}{c}0.036 * * * \\
(0.011)\end{array}$ & $\begin{array}{c}0.036 * * \\
(0.014)\end{array}$ \\
\hline Quality of government & $\begin{array}{c}-0.112 * * \\
(0.044)\end{array}$ & $\begin{array}{c}-0.064^{* * *} \\
(0.014)\end{array}$ & $\begin{array}{c}-0.030 * * * \\
(0.008)\end{array}$ & $\begin{array}{c}-0.032 * * * \\
(0.010)\end{array}$ \\
\hline Government investment & $\begin{array}{l}-1.414 \\
(2.121)\end{array}$ & $\begin{array}{l}-0.627 \\
(0.758)\end{array}$ & $\begin{array}{l}-0.276 \\
(0.363)\end{array}$ & $\begin{array}{l}-0.289 \\
(0.443)\end{array}$ \\
\hline Decentralization & $\begin{array}{c}-0.010 * * * \\
(0.003)\end{array}$ & $\begin{array}{l}-0.002 \\
(0.001)\end{array}$ & $\begin{array}{c}-0.001^{* *} \\
(0.000)\end{array}$ & $\begin{array}{c}-0.002 * * \\
(0.001)\end{array}$ \\
\hline Transition & $\begin{array}{l}-0.055 \\
(0.097)\end{array}$ & $\begin{array}{l}-0.017 \\
(0.030)\end{array}$ & $\begin{array}{l}-0.010 \\
(0.015)\end{array}$ & $\begin{array}{l}-0.015 \\
(0.019)\end{array}$ \\
\hline Ethnic fractionalization & $\begin{array}{l}-0.381 \\
(0.298)\end{array}$ & $\begin{array}{c}-0.348 * * * \\
(0.106)\end{array}$ & $\begin{array}{c}-0.110^{* *} \\
(0.043)\end{array}$ & $\begin{array}{l}-0.092 \\
(0.055)\end{array}$ \\
\hline Ethnic segregation & $\begin{array}{c}0.727 \\
(0.494) \\
\end{array}$ & $\begin{array}{c}0.451 * * \\
(0.185)\end{array}$ & $\begin{array}{c}0.163^{* *} \\
(0.076)\end{array}$ & $\begin{array}{c}0.154 \\
(0.095) \\
\end{array}$ \\
\hline Time dummies & Yes & Yes & Yes & Yes \\
\hline R-squared & 0.675 & 0.710 & 0.730 & 0.712 \\
\hline Countries & 21 & 21 & 21 & 21 \\
\hline Observations & 252 & 252 & 252 & 252 \\
\hline
\end{tabular}


At the same time, the estimates reveal the existence of a negative link between quality of government and regional inequality (Ezcurra and Rodríguez-Pose, 2014b). That is, countries with better quality of government experience in general lower levels of regional disparities. In order to complement these results,

Figure 3: ReGional ineQuality AND tRADE OPEnNESS.

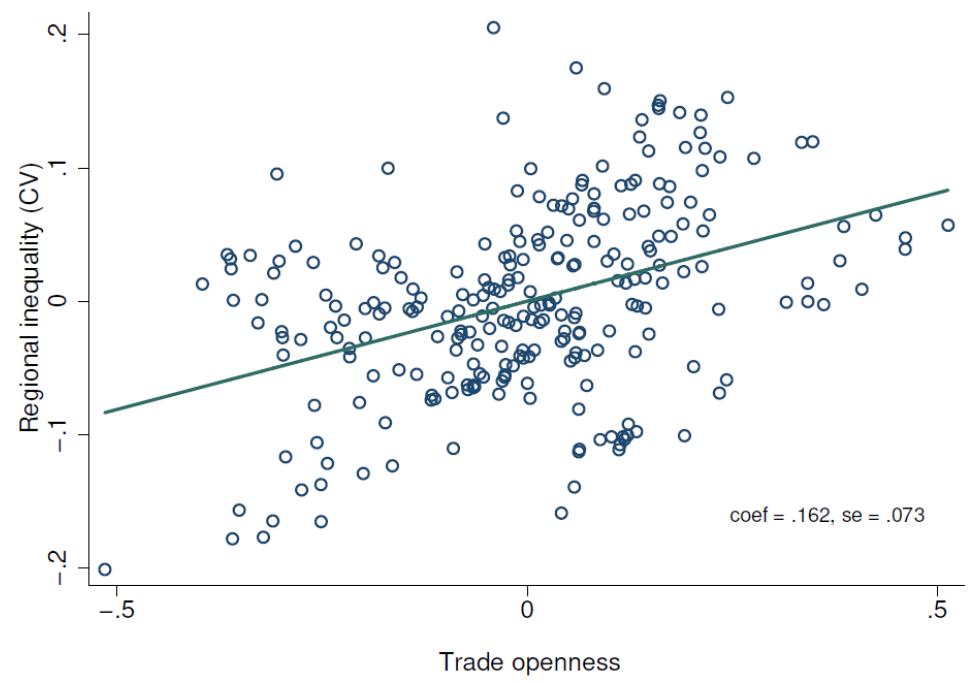

FIGURE 4: REGIONAL INEQUALITY AND QUALITY OF GOVERNMENT.

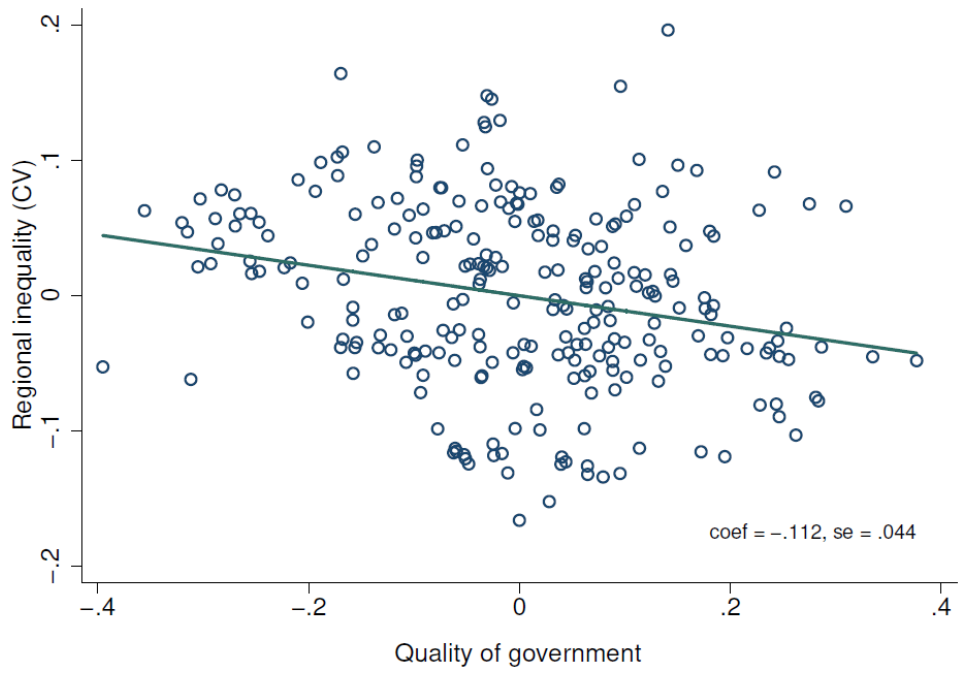


Figures 3 and 4 illustrate graphically the relationship between trade openness, quality of government and regional inequality by means of the corresponding partial regression plots based on all covariates.

The remaining regressors included in model (5) are not statistically significant in a consistent way across the various regressions in Table 4. Indeed, the existence of a significant association between some of the covariates (e.g. the level of decentralization or the degree of ethnic segregation) depends ultimately on the specific measure of regional inequality used as dependent variable. This highlights the importance in this type of analysis of checking the robustness of the conclusions against various measures of regional inequality (Ezcurra and Rodríguez-Pose, 2009).

Given that our study period is relatively short, the empirical approach used so far exploits the variations in annually repeated cross-country data in order to maximize the number of observations, thus reducing the collinearity between the regressors and improving the efficiency of the estimates (Baltagi, 2001). An alternative strategy would be to divide the time span under analysis into fouryear periods and use the mean of the different measures of regional inequality in each period as dependent variable with the time-varying regressors taken at the beginning of each period. Although this latter approach may be preferable to minimize the potential impact of the business cycle and simultaneity bias (Lessmann, 2014), the employment of four-year periods comes at the cost of ignoring valuable information on changes in regional inequality and in the time-varying regressors within any given four-year interval. In any case, Table 5 shows that the results obtained when we adopt this alternative approach are very similar to those in Table 4, which confirms the robustness of our findings.

\section{CONCLUSIONS}

This paper has examined spatial disparities in terms of development within EU countries, using data for 272 NUTS2 regions in the current 28 member states over the period 1996-2010. The analysis carried out confirms that within-country inequality is an important component of overall inequality across European regions. Indeed, regional inequality increased in most EU countries throughout the study period. The results also underline the relevance of national development for within-country inequality, although the relationship is not linear. The advances in national GDP per capita first increase regional inequality. However, beyond a threshold level, the link turns from positive to negative and richer countries tend to experience lower levels of regional inequality. Moreover, the opening of national borders to international markets is associated with higher regional inequality in the EU countries. At the same time, countries with better quality of government have lower levels of regional inequality. These results do not depend on the specific measure used to quantify the magnitude of regional disparities within the sample countries. 
TABle 5: Robustness Analysis: Four-year PERIODS.

\begin{tabular}{|c|c|c|c|c|}
\hline & $(1)$ & (2) & (3) & (4) \\
\hline Dependent variable & $\mathrm{CV}$ & G & $T(0)$ & $T(1)$ \\
\hline \multirow[t]{2}{*}{ Average size of regions } & $-0.127 * *$ & $-0.043^{* *}$ & $-0.019 * *$ & $-0.024^{* *}$ \\
\hline & $(0.052)$ & $(0.020)$ & $(0.009)$ & $(0.010)$ \\
\hline \multirow[t]{2}{*}{ GDP per capita } & $6.107^{* * *}$ & $1.899 * * *$ & $1.249 * * *$ & $1.524 * * *$ \\
\hline & $(1.502)$ & (0.535) & $(0.245)$ & $(0.320)$ \\
\hline \multirow[t]{2}{*}{ GDP per capita squared } & $-0.309 * * *$ & $-0.098 * * *$ & $-0.063^{* * *}$ & $-0.077 * * *$ \\
\hline & (0.078) & $(0.028)$ & (0.013) & $(0.016)$ \\
\hline \multirow[t]{2}{*}{ Urban population } & -0.045 & 0.100 & -0.006 & -0.019 \\
\hline & (0.193) & $(0.081)$ & $(0.030)$ & $(0.038)$ \\
\hline \multirow[t]{2}{*}{ Area } & $0.104^{* *}$ & $0.036^{* *}$ & $0.015^{* *}$ & $0.019 * *$ \\
\hline & $(0.043)$ & $(0.016)$ & $(0.007)$ & $(0.008)$ \\
\hline \multirow[t]{2}{*}{ Variation in elevation } & $0.366^{*}$ & 0.101 & $0.060 * *$ & $0.075^{* *}$ \\
\hline & $(0.176)$ & $(0.061)$ & $(0.027)$ & $(0.036)$ \\
\hline \multirow[t]{2}{*}{ Ruggedness } & $-0.727 * *$ & -0.148 & $-0.131 * *$ & $-0.177^{* *}$ \\
\hline & $(0.322)$ & $(0.120)$ & $(0.051)$ & $(0.065)$ \\
\hline \multirow[t]{2}{*}{ Trade openness } & $0.139 *$ & $0.101 * * *$ & $0.031 * *$ & $0.029 *$ \\
\hline & $(0.080)$ & $(0.032)$ & $(0.013)$ & $(0.016)$ \\
\hline \multirow[t]{2}{*}{ Quality of government } & $-0.095 * *$ & $-0.050 * * *$ & $-0.025 * * *$ & $-0.027 * *$ \\
\hline & (0.039) & $(0.017)$ & $(0.009)$ & $(0.010)$ \\
\hline \multirow[t]{2}{*}{ Government investment } & -0.313 & -0.099 & -0.028 & -0.017 \\
\hline & $(2.265)$ & $(0.825)$ & $(0.391)$ & $(0.470)$ \\
\hline \multirow[t]{2}{*}{ Decentralization } & $-0.009 * * *$ & -0.001 & $-0.001^{*}$ & $-0.002 * *$ \\
\hline & $(0.003)$ & $(0.001)$ & $(0.000)$ & $(0.001)$ \\
\hline \multirow[t]{2}{*}{ Transition } & -0.049 & -0.011 & -0.009 & -0.014 \\
\hline & $(0.091)$ & $(0.029)$ & $(0.014)$ & $(0.018)$ \\
\hline \multirow[t]{2}{*}{ Ethnic fractionalization } & -0.410 & $-0.351 * *$ & $-0.107 * *$ & -0.092 \\
\hline & $(0.316)$ & $(0.124)$ & $(0.049)$ & $(0.059)$ \\
\hline \multirow[t]{2}{*}{ Ethnic segregation } & 0.781 & $0.451^{* *}$ & $0.164^{*}$ & 0.161 \\
\hline & (0.519) & $(0.211)$ & $(0.084)$ & $(0.100)$ \\
\hline Time dummies & Yes & Yes & Yes & Yes \\
\hline R-squared & 0.644 & 0.678 & 0.680 & 0.671 \\
\hline Countries & 21 & 21 & 21 & 21 \\
\hline Observations & 84 & 84 & 84 & 84 \\
\hline
\end{tabular}

In any case, the findings of the paper on the determinants of within-country inequality should be treated with caution. In particular, it is important to note that the analysis carried out provides general insights on the relationship between the different covariates and within-country inequality, but it does not allow one to draw causal conclusions. This latter would require to employ an instrumental variables approach or other methods suitable for identification, 
which is beyond the scope of this paper. Future research should also investigate the impact of the Structural and Cohesion Funds on regional inequality within EU countries, updating the results obtained by Kyriacou et al. (2012). Only by addressing these issues, we will be able to have a fuller understanding on the nature of within-country inequality in the EU.

\section{REFERENCES}

Acemoglu, D. and Robinson, J.A. (2012): Why Nations Fail. The Origins of Power, Prosperity, and Poverty. Crown Business, New York.

Alesina, A. and Zhuravskaya, E. (2011): Segregation and the quality of government in a cross section of countries, American Economic Review 101 , 1872-1911.

Alesina, A., Devleeschauwer, A., Easterly, W., Kurlat, S. and Wacziarg, R. (2003): Fractionalization, Journal of Economic Growth 8, 155-194.

Alesina, A., Michalopoulos, S. and Papaioannou, E. (2016): Ethnic inequality, Journal of Political Economy 124, 428-488.

Ashraf, Q.H. and Galor, O. (2013): The 'Out of Africa' hypothesis, human genetic diversity, and comparative economic development, American Economic Review 103, 1-46.

Baltagi, B.H. (2001): Econometric Analysis of Panel Data. Second Edition. John Wiley \& Sons, New York.

Barrios, S. and Strobl, E. (2009): The dynamics of regional inequalities, Regional Science and Urban Economics 39, 575-591.

Barro, R. and Sala-i-Martin, X. (1995): Economic Growth. McGraw Hill, New York.

Behrens, K., Gaigné, C., Ottaviano, G.I. and Thisse, J.F. (2007): Countries, regions and trade: On the welfare impacts of economic integration, European Economic Review 51, 1277-1301.

Brúlhart, M. (2011): The spatial effects of trade openness: a survey, Review of World Economics 147, 59-83.

Cowell, F. (1995): Measuring Inequality, second edition. Prentice Hall, London.

Crescenzi, R., Di Cataldo, M. and Rodríguez-Pose, A. (2016): Government quality and the economic returns of transport infrastructure investment in European regions, Journal of Regional Science 56, 555-582.

Easterly, W. and Levine, R. (2003): Tropics, germs, and crops: how endowments influence economic development, Journal of Monetary Economics 50, 3-39.

European Commission (2017): Seventh Report on Economic, Social and Territorial Cohesion. European Commission, Brussels.

Ezcurra, R. (2014): Polarization trends across the European regions, R'egion et Développement 38, 2-18.

Ezcurra, R. and Pascual, P. (2007): Spatial disparities in productivity in Central and Eastern Europe, Eastern European Economics 45, 5-32. 
Ezcurra, R. and Pascual, P. (2008): Fiscal decentralization and regional disparities: Evidence from several European Union countries, Environment and Planning A 40, 1185-1201.

Ezcurra, R. and Rapún, M. (2007): Regional dynamics and convergence profiles in the enlarged European Union: A non-parametric approach, Tijdschrift voor Eco- nomische en Sociale Geografie 98, 564-584.

Ezcurra, R. and Rodríguez-Pose, A. (2009): Measuring the regional divide. In R. Capello and P. Nijkamp (eds.): Regional Dynamics and Growth: Advances in Regional Economics, pp. 329-353. Edward Elgar, Cheltenham (UK).

Ezcurra, R. and Rodríguez-Pose, A. (2013): Does economic globalization affect re- gional inequality? A cross-country analysis, World Development 52, 92103.

Ezcurra, R. and Rodrīguez-Pose, A. (2014a): Trade openness and spatial inequality in emerging countries, Spatial Economic Analysis 9, 162-182.

Ezcurra, R. and Rodríguez-Pose, A. (2014b): Government quality and spatial inequal- ity: a cross-country analysis, Environment and Planning A 46, 1732-1753.

Ezcurra, R., and A. Rodríguez-Pose (2017): Does ethnic segregation matter for spatial inequality?, Journal of Economic Geography 17, 1149-1178.

Ezcurra, R., Gil, C., Pascual, P. and Rapún, M. (2005a): Regional inequality in the European Union: Does industry mix matter?, Regional Studies 39, 679-697.

Ezcurra, R., Gil, C., Pascual, P. and Rapún, M. (2005b): Inequality, polarisation and regional mobility in the European Union, Urban Studies 42, 1057 1076 .

Hooghe, L., Marks, G., Schakel, A.H., Chapman Osterkatz, S., Niedzwiecki, S. and Shair-Rosenfield, S. (2016): Measuring Regional Authority. A Postfunctionalist The- ory of Governance, Volume I. Oxford University Press, Oxford.

lammarino, S., Rodríguez-Pose, A. and Storper, M. (2018): Regional inequality in Europe: Evidence, theory and policy implications, Journal of Economic Geography, https://doi.org/10.1093/jeg/lby021.

Kaufmann, D., Kraay, A. and Zoido-Lobatōn, P. (1999): Governance matters. World Bank Policy Research Working Paper 2196, World Bank.

Krugman, P. and Livas Elizondo, R. (1996): Trade policy and the third world metropolis, Journal of Development Economics 49, 137-150.

Kyriacou, A.P. and Roca-Sagalés, O. (2012): The impact of EU structural funds on regional disparities within member states, Environment and Planning C: Government and Policy 30, 267-281.

Kyriacou, A.P., Muinelo-Gallo, L. and Roca-Sagalés, O. (2015): Fiscal decentralization and regional disparities: The importance of good governance, Papers in Regional Science 94, 89-107.

Langbein, L. and Knack, S. (2010): The worldwide governance indicators: Six, one or none?, Journal of Development Studies 46, 350-370.

Lessmann, C. (2014): Spatial inequality and development - Is there an inverted-U relationship?, Journal of Development Economics 106, 35-51. 
Lessmann, C. and Seidel, A. (2017): Regional inequality, convergence and its determ- inants - A view from outer space, European Economic Review 92 , 110-132.

Monfort, P. and Nicolini, R. (2000): Regional convergence and international integra- tion, Journal of Urban Economics 48, 286-306.

Paluzie, E. (2001): Trade policies and regional inequalities, Papers in Regional Science 80, 67-85.

Petrakos, G., Rodrīguez-Pose, A. and Rovolis, A. (2005): Growth, integration and regional inequality in Europe, Environment and Planning A 37, 1837-1855.

Prud'homme, R. (1995): On the dangers of decentralization. World Bank Policy Research Working Paper 1252, World Bank.

Puga, D. (2002): European regional policies in light of recent location theories, Journal of Economic Geography 2, 373-406.

Putnam, R.D. (2000): Bowling Alone: The Collapse and Revival of American Com- munity. New York: Simon \& Schuster.

Qian, Y. and Weingast, B. (1997): Federalism as a commitment to preserving market incentives, Journal of Economic Perspectives 11, 83-92.

Quah, D. (1996): Regional convergence clusters across Europe, European Economic Review 40, 951-958.

Redding, S.J. (2013): Economic geography: A review of the theoretical and empirical literature. In D. Bernhofen, R. Falvey, D. Greenaway and U. Kreickemeier (eds.): Palgrave Handbook of International Trade, pp. 497-531. Palgrave Macmillan, London.

Rodrīguez-Pose, A. (2012): Trade and regional inequality, Economic Geography 88, 109-136.

Rodriguez-Pose, A. (2018): The revenge of the places that don't matter (and what to do about it), Cambridge Journal of Regions, Economy and Society $11,189-209$.

Rodríguez-Pose, A. and Ezcurra, R. (2010): Does decentralization matter for regional disparities? A cross-country analysis, Journal of Economic Geography 10, 619-644.

Rodrīguez-Pose, A. and Garcilazo, E. (2015): Quality of government and the returns of investment: Examining the impact of cohesion expenditure in European regions, Regional Studies 49, 1274-1290.

Sheather, S.J. and Jones, M.C. (1991): A reliable data-based bandwidth selection method for kernel density estimation, Journal of the Royal Statistical Society, Series B 53, 683-690.

Silverman, B. W. (1986): Density Estimation for Statistics and Data Analysis. Chap- man \& Hall, London.

Theil, H. (1967): Economics and Information Theory. North Holland, Amsterdam.

Weingast, B. (1995): The economic role of political institutions: Market-preserving federalism and economic growth, Journal of Law, Economics and Organization 11, 1-31.

Williamson, J. G. (1965): Regional inequality and the process of national development: A description of patterns, Economic Development and Cultural Change 13, 3-45. 
APPENDIX

\section{DESCRIPTION AND SOURCES OF CONTROL VARIABLES}

Average size of regions: Log of the average area of the country's regions expressed in square kilometres. Source: Own elaboration.

GDP per capita: Log of GDP per capita based on purchasing power parity (PPP). Data are in constant 2011 international dollars. Source: World Development Indicators.

Urban population: Fraction of the total population living in urban areas. Source: World Development Indicators.

Area: Log of country's total area expressed in square kilometres. Source: World Devel- opment Indicators.

Variation in elevation: Standard deviation of elevation across grid cells within a country in kilometres above sea level. Source: Ashraf and Galor (2013).

Ruggedness: Degree of terrain ruggedness of a country, calculated using geospatial data. Source: Ashraf and Galor (2013).

Trade openness: Sum of exports and imports of goods and services measured as a fraction of GDP. Source: World Development Indicators.

Quality of government: Average of the six indicators of the quality of government proposed by Kaufmann et al. (1999). The six indicators are: Voice and accountability, Political stability and absence of violence, Government effectiveness, Regulatory quality, Rule of law, and Control of corruption. Source: Worldwide Governance Indicators (World Bank).

Government investment: General government investment (gross fixed capital formation), expressed as a share of GDP. Source: IMF Investment and Capital Stock Dataset.

Decentralization: Self rule component of the Regional Authority Index (RAI), which captures the degree of authority exercised by subnational governments over those who live in its territory. Source: Hooghe et al. (2016).

Transition: Dummy variable that takes the value one if the country is a transition economy, zero otherwise. Source: Own elaboration.

Ethnic fractionalization: Measure which captures the probability that two individuals randomly drawn from the population belong to different ethnic groups. Source: Alesina et al. (2003).

Ethnic segregation: Measure which captures the degree of spatial concentration of ethnic groups within a country. Source: Alesina and Zhuravskaya (2011). 


\section{Additional TABLES}

TABle A1: CorrelAtion COEFFICIENTS BETWEen tHe VARIOUS MEASURES OF REGIONAL INEQUALITY.

\begin{tabular}{|lcccc|}
\hline & $C V$ & $G$ & $T(0)$ & $T(1)$ \\
\hline$C V$ & 1.000 & & & \\
$G$ & 0.848 & 1.000 & & \\
$T(0)$ & 0.959 & 0.867 & 1.000 & \\
$T(1)$ & 0.972 & 0.810 & 0.989 & 1.000 \\
\hline
\end{tabular}

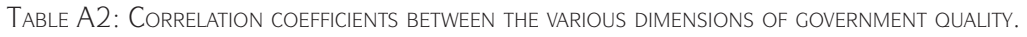

\begin{tabular}{|lcccccc|}
\hline & $\begin{array}{c}\text { Voice and ac- } \\
\text { countability }\end{array}$ & $\begin{array}{c}\text { Political } \\
\text { stability }\end{array}$ & $\begin{array}{c}\text { Government } \\
\text { effectiveness }\end{array}$ & $\begin{array}{c}\text { Regulatory } \\
\text { quality }\end{array}$ & $\begin{array}{c}\text { Rule of } \\
\text { law }\end{array}$ & $\begin{array}{c}\text { Control of } \\
\text { corruption }\end{array}$ \\
\hline $\begin{array}{l}\text { Voice and } \\
\text { accountability }\end{array}$ & 1.000 & & & & & \\
$\begin{array}{l}\text { Political } \\
\text { stability }\end{array}$ & 0.603 & 1.000 & & & & \\
$\begin{array}{l}\text { Government } \\
\text { effectiveness }\end{array}$ & 0.906 & 0.599 & 1.000 & & \\
$\begin{array}{l}\text { Regulatory } \\
\text { quality }\end{array}$ & 0.887 & 0.568 & 0.889 & 1.000 & & \\
$\begin{array}{l}\text { Rule of law } \\
\text { Control of }\end{array}$ & 0.938 & 0.588 & 0.948 & 0.916 & 1.000 & \\
corruption & 0.915 & 0.583 & 0.952 & 0.899 & 0.959 & 1.000 \\
\hline
\end{tabular}


